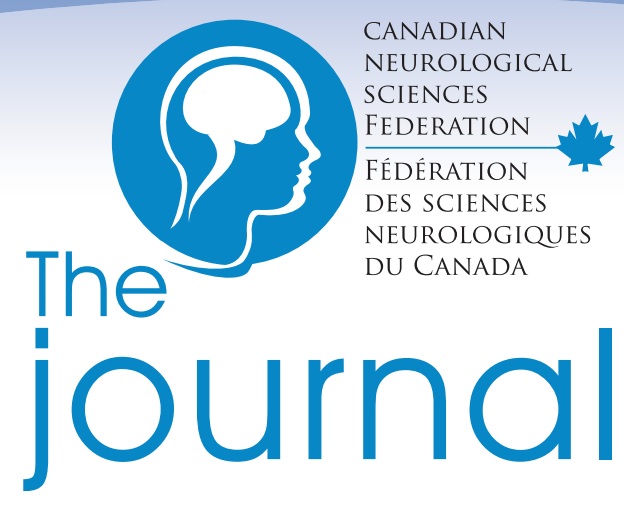

Canadian Journal of Neurological Sciences

Volume 43 (Supplement 2) June 2016

51st Annual Congress of the

Canadian Neurological

Sciences Federation

Quebec City, Quebec, Canada

51e congrès annuel de la

Fédération des sciences

neurologiques du Canada

\title{
ABSTRACTS / RÉSUMÉS
}




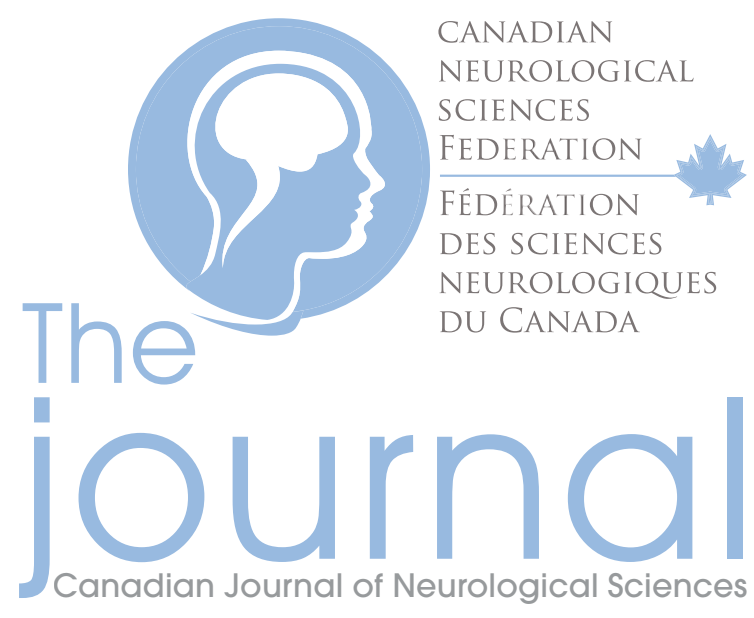

\section{REVIEWER OF THE YEAR - Dr G. Bryan Young}

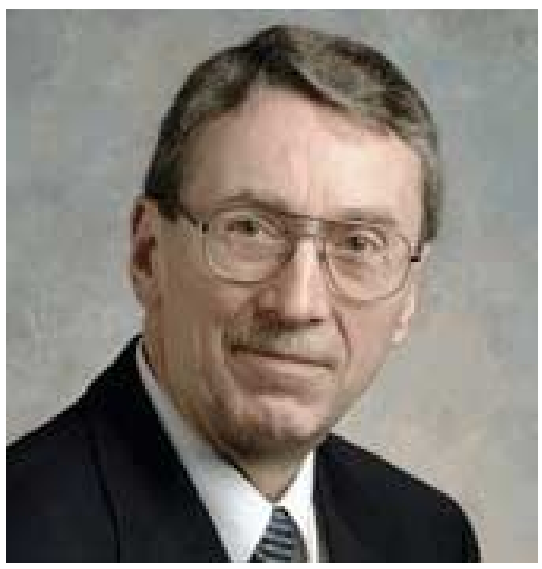

Dr. G. Bryan Young graduated from the University of Saskatchewan in 1970. His neurological, EEG and epilepsy training was at the University of Western Ontario. Dr. Young subsequently worked at teaching hospitals in Saskatoon, Toronto and London, Ontario, with his main clinical and research interest in neurocritical care. He is now semi-retired, working in Owen Sound, Ontario.

Dr. Young joined the Canadian Neurological Society in 1976 during his neurology residency and he joined the Canadian Society of Clinical Neurophysiologists in 1978. Over the past 40 years, he has served on many committees of the CNSF and as Secretary-Treasurer and President of the CSCN. Dr. Young also served on the CNSF Board of Directors from 1990-1996 and from 2007-2013, and we are proud that he is also this year's recipient of the CNSF Distinguished Service Award.

Dr. Young previously won the CJNS Reviewer of the Year award in 2004! After serving on the Editorial Board of the CJNS for many years, Dr. Young became the Editor-in-Chief of the Canadian Journal of Neurological Sciences from 2007-2013.

Dr. Young continues to contribute articles and to review manuscripts for the CJNS. Thank you, Dr Young. 


\title{
51st Annual Congress of the
}

\section{Canadian Neurological Sciences Federation \\ QUEBEC, QUEBEC CITY • JUNE 21 - 24, 2016}

\begin{abstract}
CNSF EXeCuTIVe CoMmitTeE
Jeanne Teitelbaum, CNSF/NSFC President

Kesh Reddy, CNSF/NSFC Vice President

Michael Hill, CNSF/NSFC Vice President

Sharon Whiting, CNSF/NSFC Vice-President

Dan Morin, CNSF CEO
\end{abstract}

Juliette Hukin, CNSF/NSFC Board Member - CACN President Cecil Hahn, CNSF/NSFC Board Member - CACN Vice President Ian Fleetwood, CNSF/NSFC Board Member - CNSS President Stephen Lownie, CNSF/NSFC Board Member - CNSS Vice President Colin Chalk, CNSF/NSFC Board Member - CNS President Fionna Costello, CNSF/NSFC Board Member - CNS Vice President Jose Francisco Tellez-Zenteno, CNSF/NSFC Board Member - CSCN President Fraser Moore, CNSF/NSFC Board Member - CSCN Vice President Bill Wang, CNSF/NSFC Board Member - CNSS Resident Representative Theo Mobach, CNSF/NSFC Board Member - CNS Resident Representative Leyila Kaseka, CNSF/NSFC Board Member - CACN Resident Representative Chris Ekong, CNSF/NSFC Board Member - CNSF At-large Kristine Chapman, CNSF/NSFC Board Member - CNSF At-large Robert Chen, CJNS Editor-in-Chief-CNS + CSCN Member

Tejas Sankar, CNSF SPC Chair

Joe Megyesi, CNSF PDC Chair

Richard Riopelle, CNSF Advocacy Chair-CNS Member

Shobhan Vachhrajani, CNSF CPGC Chair-CNSS Member

\section{SCIENTIFIC PROGRAM COMMITTEE \&} PROFESSIONAL DEVELOPMENT COMMITTEE

Joe Megyesi

Aleksandra Mineyko

Tejas Sankar

PDC Chair (CNSS)

PDC Vice-Chair $(C A C N)$

Alexandre Henri-Bhargava

Chintankumar Shah

Shannon Venance

SPC Chair (CNSS)

$S P C$ Vice-Chair $(C N S+C S C N)$

$P D C(C A C N)$

$P D C(C S C N)$

$P D C(C N S+C S C N)$

Rudolf Arts

Craig Campbell

James Perry

Gelareh Zadeh

$S P C(C A C N+C S C N)$

$S P C(C N S)$

$S P C$ (CNSS)

$S P C(C S C N)$

$S P C(C S C N)$

Seyed Mirsattari

Leyila Kaseka

Bill Wang

Theo Mobach

Jeanne Teitelbaum

Kesh Reddy

Sharon Whiting

$S P C+P D C$ Residents Rep $(C A C N)$

$S P C+P D C$ Residents Rep (CNSS)

$S P C+P D C$ Residents Rep $(C N S)$

CNSF/NSFC President (CNS)

CNSF/NSFC Vice President (CNSS)

$C N S F / N S F C$ Vice President $(C A C N+C S C N)$

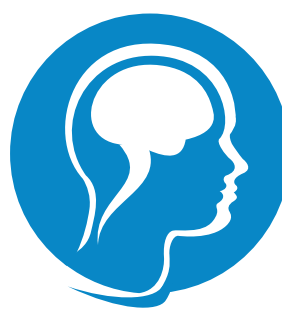

CANADIAN NEUROLOGICAL SCIENCES FEDERATION FÉDÉRATION DES SCIENCES NEUROLOGIQUES DU CANADA

\section{ABSTRACTS AND PROGRAM}

\author{
The Canadian Journal of \\ Neurological Sciences \\ and \\ The Canadian Neurological \\ Sciences Federation
}

do not assume any responsibility or

liability for any errors in the abstracts. 


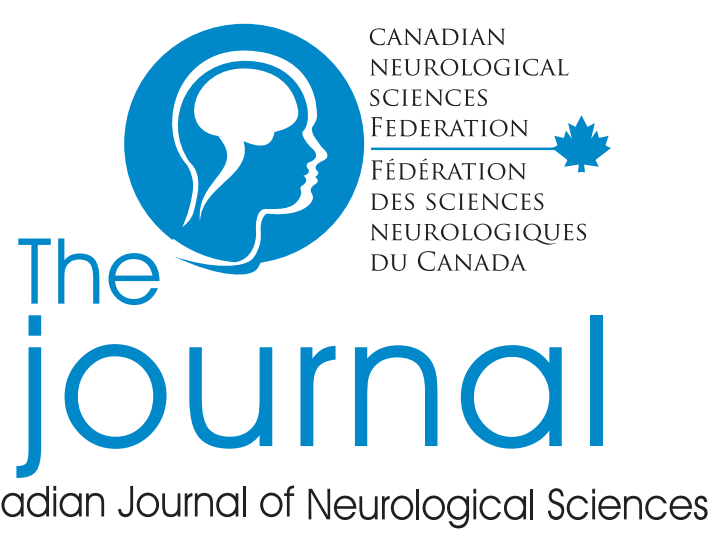

\section{Volume 43 / Supplement 2 / June 2016}

Editor-in-Chief/Rédactueur en chef

Robert Chen TORONTO, ON

\section{Associate Editors/Rédacteurs associés}

Etienne De Villers-Sidani MONTREAL, QC

Robert Hammond LONDON, ON

Hans Katzberg TORONTO, ON

Mahendranath Moharir TORONTO, ON

Tejas Sankar EDMONTON, AB

Manas Sharma LONDON, ON

Jeanne Teitelbaum MONTREAL, QC

\section{Past Editors/Anciens rédacteurs en chef}

G. Bryan Young LONDON, ON

Douglas W. Zochodne CALGARY, AB

James A. Sharpe TORONTO, ON

Robert G. Lee CALGARY, AB

Robert T. Ross WINNIPEG, MB

(Emeritus Editor, Founding Editor)

\section{Editorial Board/Comité éditorial}

Jorge Burneo LONDON, ON

Richard Desbiens QUEBEC CITY, QC

David Fortin SHERBROOKE, QC

Mark Hamilton CALGARY, AB

Hans-Peter Hartung DUSSELDORF, GERMANY

Michael Hill CALGARY, ON

Alan C. Jackson WINNIPEG, MB

Daniel Keene otTAwA, ON

James Perry TORONTO, ON

Oksana Suchowersky EDMONTON, AB

Brian Toyota VANCOUVER, BC

Brian Weinshenker ROCHESTER, MN, USA

Samuel Wiebe CALGARY, AB

Elaine Wirrell ROCHESTER, MN, USA

\section{Book Review/Critiques de livres Reflections/Reflets}

Andrew Kirk saskatoon, sK

Editorial Review Board/Comité de lecture

Donald Brunet KINGSTON, ON

Jodie Burton CALGARY, AB
Lionel Carmant MONTREAL, QC

Colin Chalk MONTREAL, QC

K. Ming Chan edmonton, AB

Joseph Dooley HALIFAX, NS

Paolo Federico CALGARY, AB

Daryl Fourney SASKATOON, SK

Hannah Glass SAN FRANCISCO, CA, USA

Alan Goodridge ST. JOHNS, NL

Ian Grant HALIFAX, NS

Alan Gruberman OTTAWA, ON

John Hurlbert CALGARY, AB

Manouchehr Javidan VANCOUVER, BC

Patrick McDonald WINNIPEG, MB

Martin McKeown vancouver, BC

Joseph Megyesi LONDON, ON

Vivek Mehta EDMONTON, AB

Steven Miller TORONTO, ON

Neelan Pillay CALGARY, AB

Christopher Power EDMONTON, AB

Alex Rajput SASKATOON, SK

Jean Raymond MONTREAL, QC

Gary Redekop VANCOUVER, BC

Harvey Sarnet CALGARY, AB

John Stewart VANCOUVER, BC

Jeanne Teitelbaum MONTREAL, QC

Eve Tsai OTTAwA, ON

Shannon Venance LONDON, ON

Matt Whetley EDMONTON, AB

Jerome Yager EDMONTON, AB

\section{Journal Staff/Effectif du Journal}

Dan Morin CALGARY, AB

Chief Executive Officer

Donna Irvin CALGARY, AB

CNSF Membership Services /

Communications Officer

\section{The official journal of: / La Revue} officielle de:

\section{The Canadian Neurological Society}

La Société Canadienne de Neurologie

The Canadian Neurosurgical Society

La Société Canadienne de Neurochirurgie

The Canadian Society of Clinical Neurophysiologists La Société Canadienne de Neurophysiologie Clinique
The Canadian Association of Child Neurology L'Association Canadienne de Neurologie Pédiatrique

The permanent secretariat for the four societies and the Canadian Neurological Sciences Federation is at:

Le sécretariat des quatre associations et de la Fédération des sciences neurologiques du Canada est situe en permanence à :

$143 \mathrm{~N}-8500$ Macleod Trail SE Calgary, Alberta T2H 2N1 Canada CNSF (403) 229-9544 / CJNS (403) 229-9575 Fax (403) 229-1661

The Canadian Journal of Neurological Sciences is published bi-monthly. The annual subscription rate for Individuals (electronic) is $£ 117 / \$ 193$. The annual subscription rate for Institutions (electronic) is $£ 156 / \$ 259$. See <www.journals. cambridge.org/cjn > for full details including taxes; e-mail: subscriptions_ newyork@ cambridge.org. The Canadian Journal of Neurological Sciences is included in the Cambridge Journals Online service, which can be accessed at www.journals.cambridge.org. For information on other Cambridge titles, visit www.cambridge.org. For advertising rates contact M. J. Mrvica Associates, 2 West Taunton Avenue, Berlin, NJ 08009; Phone: 856-768-9360; Fax: 856-7530064; Email: mjmrvica@mrvica.com.

Le Journal Canadien des Sciences Neuorlogiques est publié tous les deux mois. Le prix d'abonnement annuel pour les individus (électronique) est $111 £ / 184 \$$. Le prix d'abonnement annuel pour les établissements (électronique) est $125 £ / 207 \$$. Veuillez consulter <www.journals.cambridge.org/cjn $>$ pour tous les détails, y compris les taxes; email: subscriptions_newyork@cambridge.org. Le Journa canadien des sciences neurologiques est inclus dans le service Cambridge Journals Online, accessible à www.journals.cambridge.org. Pour plus d'informations sur les titres disponible chez Cambridge, veuillez consulter www. cambridge.org. Pour les tarifs de publicité, contacter M. J. Mrvica Associates,

2 West Taunton Avenue, Berlin, NJ 08009; Téléphone: (1)856-768-9360; Email: mjmrvica@mrvica.com.

This journal is indexed by / Cette revue est indexée par:

Adis International, ArticleFirst, BIOBASE, BioLAb, BiolSci, BIOSIS Prev, Centre National de la Recherche Scientifique, CSA, CurAb, CurCont, De Gruyter Saur, E-psyche, EBSCO, Elsevier, EMBASE, FRANCIS, IBZ, Internationale Bibliographie der Rezensionen Geistes-und Sozialwissenschaftlicher Literatur, MEDLINE, MetaPress, National Library of Medicine, OCLC, PE\&ON, Personal Alert, PsycFIRST, PsycINFO, PubMed, Reac, RefZh, SCI, SCOPUS, Thomson Reuters, TOCprem, VINITI RAN, Web of Science.

ISSN: 0317-1671

EISSN: 2057-0155

COPYRIGHT @ 2016 by THE CANADIAN JOURNAL OF NEUROLOGICAL SCIENCES INC. All rights reserved. No part of this publication may be reproduced, in any form or by any means, electronic, photocopying, or otherwise, without permission in writing from Cambridge University Press. Policies, request forms and contacts are available at: http://www.cambridge.org/about-us/rights-permissions. Permission to copy (for users in the U.S.A.) is available from Copyright Clearance Center: http://www.copyright.com, email: info@ copyright.com.

COPYRIGHT @ 2016 du THE CANADIAN JOURNAL OF NEUROLOGICAL SCIENCES INC. Tous droits réservés.

Aucune partie de cette publication ne peut être reproduite, sous quelque forme ou par quelque procédé que ce soit, électronique ou autre, y compris la photocopie, sans l'accord écrit de Cambridge University Press. Les politiques, les formulaires de demande et les contacts sont disponibles à: http://www.cambridge.org/aboutus/rights-permissions. La permission de copier (pour les utilisateurs aux ÉtatsUnis) est disponible auprès Copyright Clearance Center: http://www.copyright com, email: info@copyright.com. 


\section{Abstracts}

\section{Platform Presentations}

\section{Wednesday, June 22, 2016}

A. CACN Chair's Select Abstract Presentations A.01 to A.06 S7

B. CNS/CSCN Chair's Select Abstract Presentations B.01 to B.07. S9 Includes CNS Francis McNaughton Memorial Prize, CSCN Herbert Jasper Prize, and CNS André Barbeau Memorial Prize

C. CNSS Chair's Select Abstract Presentations C.01 to C.07 $\mathrm{S} 11$

Includes CNSS K.G. McKenzie Prizes in Basic Neuroscience Research and CNSS K.G. McKenzie Prizes in Clinical Research
Friday, June 24, 2016

D. CACN/CSCN Platform Presentations D.01 to D.11 S13

E. CNS Platform Presentations E.01 to E.11 S16

F. CNSS Platform Presentations F.01 to F.11 $\mathrm{S} 18$

\section{Poster Presentations}

\section{Thursday, June 23, 2016}

\section{CHILD NEUROLOGY}

Epilepsy and EEG - P.001 .

General Pediatric Neurology - P.002 to P.006 .... S22

Neuromuscular Care - P.007

\section{MULTIDISCIPLINARY}

P.009 to P.016

\section{NEUROLOGY}

Dementia, Aging, and Cognitive - P.019. $S 25$

Epilepsy and EEG - P.020 to P.028 S26

General Neurology - P.029 to P.041. $S 28$

Movement - P.042 to P.047. S31

Multiple Sclerosis/Neuroinflammatory - P.049 to P.052. S32

Neurocritical Care/Neuro Trauma - P.054

Neuromuscular - P.055 to P.060. S33

Stroke - P.061 to P.067
NEUROPHYSIOLOGY

EEG - P.068 to P.073. S37

\section{NEUROSURGERY}

Critical Care/Neuro Trauma - P.075 to P.082.... S38 Functional Neurosurgery and Pain - P.083 to P.087. $\mathrm{S} 40$

General Neurosurgery - P.089 to P.094 …......... S41

Neuro Interventional - P.095 to P.100 ............... S42

Neuro Oncology - P.103 to P.109...................... S44

Neuro Vascular (Adult and Pediatric) - P.111 to P.121.................................................... S46

Pediatric Neurosurgery - P.122 to P.127 ............ S48

Spine and Peripheral Nerve - P.128 to P.138 ..... S49

Congress-at-a-Glance S6

AUTHORS INDEX S53 


\section{Canadian Neurological Sciences Federation 2016 Congress June 21 - 24 Quebec City Convention Centre}

Tuesday, June 21st, 2016

8:30 AM to 11:30 AM - Courses

- Hot Topics in Neurology: Ethics/Physician Assisted Death.

- $\quad$ Hot Topics in Child Neurology: Hypothermia for perinatal asphyxia and new treatments for epilepsy

- $\quad$ Hot Topics in Neurosurgery: Ethics/Physician Assisted Death

- $\quad$ Hot Topics in Clinical Neurophysiology: Psychiatric Comorbidity in Epilepsy

- $\quad$ Neurology Resident Course: Neurophysiology/Electroencephalography

11:45 AM - 1:15 PM - Lunch 'n Learn (Unaccredited)

- $\quad$ Opportunistic infection risk over time during the treatment course of MS

- New Anti-Epileptic Drugs in Canada: From Basic Mechanisms to Use in Clinical Practice

1:30 PM to 4:30 PM - Resident Courses

- Neurosurgery: Neurovascular

- Neurology: EMG and Neuromuscular Disease Basics

1:30 PM to 4:30 PM - Courses

- $\quad$ Conducting Independent Medical Exams

- Functional Mapping in Cranial Surgery

5:30 PM to 7:30 PM - Clinical Case Studies (CCS)

- $\quad$ Epilepsy Video Session

- Practical Neurosurgery

- Neuromuscular

- Headache: Chronic Migraine

Wednesday, June 22nd, 2016

8:00 AM to 10:30 AM - Grand Plenary

- $\quad$ CNS - Richardson Lecture: Michael Hill - Acute Stroke Treatment

- $\quad$ CSCN - Gloor Lecture: Andres Kanner- Laser-Ablation of Mesial Temporal Structures

- $\quad$ CACN - Tibbles Lecture: Kym Boycott - Canada's Path Forward for Rare Genetic Diseases

- $\quad$ CNSS - Penfield Lecture: Juha Hernesniemi - Microsurgery of Cerebral AVMs

10:45 AM to 12:30 PM - SPC Chair's Select Abstracts - (Selected as part of Abstract Review Process)

12:30 PM to 2:00 PM - Lunch 'n Learn (Unaccredited)

- Challenges and Pitfalls of Epilepsy Management in Clinical Neurology

- $\quad$ Evolving Treatment Paradigms in Neuroscience: The Sooner the Better

2:15 PM to 5:15 PM - Multi-disciplinary Courses

- $\quad$ Neurocritical Care

- $\quad$ Stroke

- Neuromuscular

- Tumour Related Epilepsy

- Difficult Problems in Headache Medicine

5:15 PM to 7:15 PM - Exhibitors' Reception

Thursday, June 23rd, 2016

7:00 PM to 9:00 PM - Residents' Social

8:30 AM to 4:30 PM - Society Days

- $\quad$ Child Neurology (CACN) Day

- $\quad$ Child Neurology (CACN) Day

- $\quad$ Neurophysiology (CSCN) Day

- $\quad$ Neurophysiology (CSCN) Day

- $\quad$ Neurology (CNS) Day

- $\quad$ Neurology (CNS) Day

- $\quad$ Neurosurgery (CNSS) Day

- $\quad$ Neurosurgery (CNSS) Day

- $\quad$ Neurosurgery (CNSS) Day

- $\quad$ Neurosurgery (CNSS) Day

AM - Rare Diseases

PM - Rare Diseases

AM - Neuromuscular Weakness in the Intensive Care Unit

$P M-E E G$ in the Critical Care Unit

AM - Neuromyelitis Optica Spectrum Disorders

PM - Multiple Sclerosis - The Good, the Bad and the Ugly

AM - What's New in Spine?

AM - Pediatric/Congenital Neurosurgery-Hydrocephalus Management

PM - Recent Trends in Stereotactic Radiosurgery

PM - Innovations in Neurosurgical Education

11:45 AM to 1:15 PM - Lunch 'n Learn (Unaccredited) - Practice Audits in Multiple Sclerosis

$11: 45$ AM to $1: 15$ PM - Lunch in the Exhibit Hall

4:45 PM to 6:30 PM - Digital Poster Author Standby Sessions

7:00 PM - CNSF Social Event, Chateau Frontenac - "A Taste of Quebec"

Friday, June 24th, 2016

8:30 AM to 11:30 AM - Multi-Disciplinary Courses

- $\quad$ Adult Hydrocephalus Diagnosis and Treatment

- $\quad$ Tropical Neurology/Neuro-infectious Diseases

- Disorders of Consciousness - an update

8:30 AM to 11:30 AM - Abstract Platform Presentations - CACN/ CSCN, CNSS, CNS

11:30 AM to 1:00 PM - Brunch in Exhibit Hall

1:00 PM to 3:00 PM - Grand Rounds 